\title{
IN SUPPORT OF PRACTICE-BASED TEACHER PROFESSIONAL LEARNING
}

\author{
R. Jeram* \\ Centre for Pedagogy in the Faculty of Education \\ e-mail: ramesh@sun.ac.za / https://orcid.org/0000-0001-5485-9863
}

\section{N. Davids* (Correspondence)}

Department of Education Policy Studies

e-mail: nur@sun.ac.za / https://orcid.org/0000-0002-7588-5814

*Stellenbosch University
Stellenbosch, South Africa

\section{ABSTRACT}

Research indicates that teacher education programmes are impeded by abstract, theory-laden and decontextualised modes of teacher professional development. As a result, teachers have particular sets of pedagogical knowledge without a clear understanding of how this knowledge ought to be implemented in diverse classroom settings. As an alternative response, an argument is made for a practice-based teacher professional learning approach. By analysing theories around practice (practice theory) and the concept professional learning, we propose, firstly, that teacher professional learning programmes should include pedagogies for learning that are continuous, intensive, socially mediated, supportive, embodied and relate to the contextual needs of the teacher. Secondly, that teachers ought to be provided with the skills, necessary for the conversion of theoretical ideas into practice. Thirdly, we contend that a practice-based teacher professional approach requires teacher agency in relation to their practices, as opposed to merely implementing various strategies and approaches.

Keywords: professional learning, practice theory, teacher education, teacher agency, practicebased teacher professional learning

\section{INTRODUCTION AND BACKGROUND}

There is seemingly no shortage of studies on what is often described as poor teacher content knowledge; inadequate teaching methodologies; and a general unpreparedness to teach. A number of teachers in South African schools, it would seem, are unprepared for what it means to be an effective teacher in South African classrooms - but for two seemingly different reasons. On the one hand, is the commonly cited gap between theory and practice. Teacher participants in a study conducted by Gravett and Ramsaroop $(2015,136)$, describe teacher education as "too theoretical" or "theory laden", meaning that too much emphasis is placed on theories of learning 
and teaching during teacher education programmes, and thus teachers become disconnected from their practice in the context of the classroom.

As a result, novice teachers have knowledge, that is not relevant to their teaching practice within their classroom; they "walk with lots of book knowledge, but little practical experience" (Gravett and Ramsaroop 2015, 136). Despite teachers being exposed to theories around teaching and learning, most teachers have difficulty in transposing these theories into practice, within their classroom context (Korthagen and Kessels 1999; Feiman-Nemser 2001; Kiggundu and Nayimuli 2009; Zeichner 2010; Anderson and Freebody 2012; Spaull 2013; Sayed et al. 2018). According to Korthagen and Kessels (1999), when teacher education programmes emphasise theory without much reference to practice, teaching becomes procedural and routinised. The point that they make is that the perceived gaps that exist between theory-laden university-based programmes, which focusses on theories relating to teaching and learning and the contexts of how teachers practice in schools, are not unique to South African teachers. In addition, there is the growing concern of inadequate teacher content knowledge. Findings by Spaull (2013) and Van der Berg, Spaull, Wills Gustafsson and Kotze (2016) reveal that South African teachers have lower subject content knowledge than their peers in sub-Saharan Africa countries, and are even sometimes outperformed by learners they are supposed to be teaching. In turn, Van der Berg and Hofmeyr (2017) found that the relatively weak content knowledge of South African teachers impairs their ability to accurately judge their learners' performance, and hence, their ability to improve learner performance.

While the prevalence of inadequate or poor teacher content knowledge is decidedly different from having too much theoretical knowledge, the outcome, however, is the same and that is teacher unpreparedness. Exacerbating the complexities of teacher unpreparedness are often unfamiliar and alienating estranging school contexts. To be unaware of the legacies of apartheid, for example, argues Davids $(2019,46)$, is to lack an understanding of severe oppression and marginalisation, which continue to feed into the psyches and self-esteems of teachers and learners, alike. It is not unusual, therefore, argues Farber and Wechsler $(1991,36)$, to find that although teachers start their careers, with the hope of being agents of change, and making a difference in the lives of their learners, many of them face unprecedented challenges, ethical dilemmas, and vulnerabilities, leaving them to feel a "sense of inconsequentiality". As a result, teachers, particularly those in the very early grades, find it hard to face the challenges of everyday classroom practice, and often exit their profession after only a few years (Henning and Gravett 2011; Kennedy 2016).

In recognising the challenges of theory-laden teacher education programmes, and decontextualised modes of teacher professional development, we argue in this article for a 
practice-based teacher professional learning approach to teacher education programmes. That is, an approach, which looks at how aspects of practice theory could be incorporated into theoretically focused teacher education programmes, leading to pedagogies for learning that are continuous, intensive, socially mediated, supportive, embodied and relate to the contextual needs of the teacher, to address the theory-practice divide.

Before we commence with our discussion, it is necessary for us to clarify what we mean by practice-theory, and the role it could play in arguing for the phenomenon of practice-based teacher professional learning approach. Starting from the premise of what a theory is, Schatzki $(2001,12)$ defines theory as an account of something, that is, something that is known or observed. A theory could also provide an opportunity for meaning making and understanding, thus for Schatzki (2001), a theory of education relates to what is known about education and a theory of practice relates to what is known about practice. A commonly held view is that theory is simply the opposite of practice (Thomas 1997) - so that theory is that which practice is not. Yet, when we consider the concepts of theory and practice, it becomes apparent that theory and practice are mutually contingent - that is, that theory is informed by practice, and, in turn, practice is informed by theory. Davids and Waghid, for example, describe the nexus between theory and practice as "a rhythmic action" $(2017,9)$ - when teachers teach "they need both the theory of education and the practice of teaching to do so. Similarly, when students learn, they need the theory, and the practical application thereof in order to demonstrate that they have indeed learnt" (Davids and Waghid 2017, 6). Our coining of the term practice-theory is in recognition of what we consider as the mutual dependency and relationality between practice and theory. To treat the two concepts of theory and practice as separates, is to lose sight of their inter-relational subjectivity. Teaching, and by implication, learning, needs theory, but it is only through practice that this need becomes evident. Hence, the concept of practice-theory gives expression to the inter-dependency between practice and theory.

\section{THE PROBLEMS WITH TEACHER EDUCATION PROGRAMMES: A THEORY- PRACTICE DIVIDE}

Teachers generally attend professional development sessions because they feel a need to keep abreast of what is current within the teaching environment. As curricula change, the need for teacher professional development becomes more important as teachers need to upskill themselves and become au fait with the new principles, outcomes and objectives of the curriculum. However, research indicates that professional development activities are not delivering on their mandate to enhance teaching practices and improve opportunities for learners to learn (Ball 2000; Ball and Bass 2000; NEEDU 2012; Korthagen 2001). These 
researchers claim that professional development activities are not influencing teacher efficacy and the quality of education positively because the current professional development activities focus mainly on content and not much on bridging the theory-practice divide.

There are concerns by school administrators, parents and politicians about the insufficient way in which teachers are prepared for everyday practice in the classroom (Korthagen, Loughran and Russell 2006). This lack of preparation is a consequence of too much emphasis being placed on theory within teacher education programmes. After a worldwide study on teacher education programmes, researchers Imig and Switzer (1996) concluded that the emphasis of imparting theoretical expert knowledge is not having much influence on the practice of teachers. German researchers concluded that during year one of their teaching, teachers adjust to the practices of the school, which is not based on theories relating to teaching and learning (Korthagen and Kessels 1999). In a more recent study, Korthagen et al. (2006) conclude that the transfer from theory (presented during teacher education) to practice in schools is often meagre, and teacher education practices are often counterproductive to teacher learning.

Much of the debate surrounding theory, it would, seem emanates from an understanding that theory stands disconnected from practice - that is, that theory is what practice is not (see Thomas 1997; Carr 2006). From a modernists perspective, Hirst (1963), claims that theory is viewed as creating the norms for practice, irrespective of the context whilst Carr (2006) on the other hand, from a post-modernist perspective, makes a case for practices being the dominant force in creating theory, linked to a particular context. For Higgs $(2013,105)$, it is indisputable that theory plays an important role not only in teacher content knowledge, but also in educational research and practice in teacher education. She contends that "theory seeks to emancipate teachers from their dependency on practices that are the product of ideological and political constructs while at the same time allowing teachers to critically reflect on their practice in the classroom". It does this, she continues, "by means of critical modes of enquiry that are aimed at exposing and examining the beliefs, assumptions and values implicit in ideological and political agendas which often determine how teachers organize their experiences and practices in the classroom" (Higgs 2013, 105).

Educational theory, claims Hirst (1963), is a system of rules governing actions or practices, but when applying this system of rules educational theory loses its fluidity to make value-driven judgments related to teaching on what shall and what shall not be done. However, for Carr (2006, 136), "Educational theory has been criticised for being nothing other than the name given to the various futile attempts to stand outside of educational practices in order to explain and justify them". Adding credence to this claim, Jeram (2017), in a study with 
mathematics teachers in the classroom, noted that because teaching is such a value-laden and emotive activity, the emotions and moods of those enacting teaching are regularly confronted by different contexts. These sort of complexities determine the most likely form of teaching activity or practices that could take place - leading Jeram (2017) to conclude that the knowledge or epistemology of a teacher's practice develops because of their experience and linked to what could possibly be applicable within their teaching context, and not on any formal educational theory per se. Their experience and beliefs drive their decisions on their practices, linked to a particular context. A view similar to Carr's $(2006,149)$ contention which states that "in 'articulating' their beliefs in this way, practitioners are neither engaging in 'theoretical activity' nor articulating their 'theoretical position'. What they are articulating are the beliefs that underwrite their practice not their allegiance to some theory". For Carr (2006), as theory converges onto practice, practice simultaneously converges onto theory linked to the contextual needs of the practitioner, in this case the teacher.

Strengthening this view of theory and practice converging onto each other, is a conception taken further by Davids and Waghid (2017) and Waghid and Davids (2017). "To avoid theory is to become unmindful of what a practice actually is. That is, theory and practice are interrelated and constitute a nexus according to which they unfold in forms of human action" (Davids and Waghid 2017). To further understand this nexus, and using the Aristotlean notions of phronesis, poiesis and praxis, they offer a different view of how theory might relate to practice. Phronesis could be considered the thought processes associated with a particular practical action. Poiesis means "production" of that practical action and it is understood as that which is in the making - with an emphasis on the actual process of developing the enactment, rather than the product or the enactment itself.

During poiesis, one theorises and performs a practice because of this process. Praxis is the actual practical action of this "production" or poiesis (Waghid and Davids 2017). The practical action is considered as liberatory in the sense that it sets the "production" free from its theoretical musings, namely phronesis and poiesis. Thus, phronesis, poiesis and praxis, or stated differently, "knowing that" and "knowing how" (Ryle 1945) or the creation of tacit and explicit knowledge (Polanyi 1966), are ongoing but they are never distinct from each other. When viewed in this way, it becomes apparent that theory and practice are unavoidably intertwined, and always espoused as an interrelationship, never a dichotomy (Davids and Waghid 2017; Waghid and Davids 2017).

In educational contexts the discomfort around theory is exacerbated by what Thomas $(1997,76)$ refers to as "the absence of the community language system by which education academics and researchers understand theory". Hence, and rightly so, teachers in South African 
schools often lament the omission of context from theoretical prescriptions of what and how teachers ought to teach (Kennedy 2016). In sharing the findings of a teacher education programme geared at mathematics educators, Jeram (2017), for example, reports that while teachers acknowledged the benefits of teacher education programmes, they raised concerns and criticisms that the programmes paid scant attention to addressing the theory-practice divide in a classroom setting. Moreover, there appeared to be an implicit assumption - at least in terms of the delivery of the teacher education programmes - that classrooms were somehow homogeneous spaces. Not only are teachers confronted with complex realities and deficiencies in terms of poor teaching and learning resources, but by learners, who often inadequately prepared due to particular sets of socio-economic contexts, which are beyond the control of a teacher. As a result, the teachers, reported on by Jeram (2017), understood what was happening within the framework and discourse of a teacher education training programmes, but they expressed little hope that these theory laden and decontextualised programmes would improve their efficacy in a classroom setting. This is because teachers struggle to find bridges between what they learn about teaching (theory), and the reality of the classroom in which they are expected to practice or enact the theory. The ensuing disconnection between what is known (as in the theory), and what is experienced or practiced, in the classroom, results not only in a rather sceptical impression of theory, but in a deliberate avoidance to implement such theory. In providing a different perspective as a facilitator of professional development programmes, Steyn $(2008,18)$ notes that many teachers do not have the ability to reflect critically on their own practice, nor to try out new solutions to solve problems they encounter daily.

Yet, irrespective of teachers' criticisms of teacher education programmes and workshops, research confirms that learner performance especially in mathematics continues to be low, and that poor teacher knowledge has to be addressed (Adler and Venkat 2014; Jeram 2017). Moreover, according to Pournara, Hodgen, Adler and Pillay (2015), despite numerous years of mathematics professional development programmes aimed at redressing the devastating effects of apartheid schooling and apartheid teacher education, there is little evidence to show we have made much progress at the level of the learner. Claims of lack of impact are typically based on results of summative national and international assessments, such as the Trends in International Mathematics and Science Study (TIMSS), Programme for International Student Assessment (PISA), Southern Africa Consortium for Monitoring Education Quality (SACMEQ), the Annual National Assessments (ANA), and the National Senior Certificate (NSC) exams (Pournara et al. 2015). Adding to this complexity, is that, as yet, there are no adequate frameworks for evaluating the impact of professional development in South Africa (Pournara et al. 2015). 
That teachers, however, are at the centre of improving learner performance, cannot be contested. That they have the "most direct, sustained contact with students, as well as considerable control over what is taught and the climate of learning" (King and Newman 2001, 86), means that teachers not only have to know what and how to teach, but that their professional development is key to learner performance. As such, teachers, asserts Rusznyak $(2018,2)$ "need to be educated (not merely trained), and should intentionally use a knowledge base to support their teaching practices (not merely indiscriminately apply a set of techniques and routines)" within the contextual challenges of an emerging economy overcoming a legacy of inequality. Teaching is thus context-dependent and not context-free, and it should be particular (intense) and not general, concrete as opposed to abstract. According to Waghid and Davids (2017), when teachers prepare lessons, they are involved in the process of "making", and, when one is in the process of making, you start to develop a theoretical viewpoint of how the practices within the classroom are to be enacted. For Waghid and Davids (2017), this is considered the germination of a teacher's own educational theory, linked to a particular context, as the teacher now has a blueprint of how the lesson will be enacted within that context.

Taking these criteria into account, professional learning of teachers should be about constantly having to make adjustments to their blueprint whilst enacting the practice in the context of their classroom, bringing into view Waghid and Davids' (2017) argument that theory and practice cannot be viewed as two independent entities; they form a nexus. They claim that there is no unidirectional feed of one into the other, but rather a bidirectional to-ing and fro-ing. One's thoughts (theories) guide your practice, but your practices are constantly generating new thoughts (theories) to adapt and improve your practices. Phronesis, poiesis and praxis are mutually contingent on each other and do operate within silos.

In attempting to address the challenge in minimising the theory-practice divide within teacher education programmes, we suggest practice-based teacher professional learning as an alternative approach to teacher education programmes. Embedding the notion of continuous professional learning into the reality of what we do and not outside of where we practice, leading researchers such as Timperley (2008), Boud and Rooney (2011) and Raelin (2007) suggest that to bridge the theory-practice divide, professional learning should be based on practice theory. This practice-based professional learning approach calls for the intermingling of theory and practice - specifically, that theory and practice are mutually contingent, and should not be approached and adopted as two separate entities. To bridge the theory-practice divide, a kind of teaching and learning where teachers elicit changes in their practice, taking into account the contexts within which teachers learn and teach and not just implement strategies and activities learnt at workshops. 


\section{ELEMENTS OF PRACTICE-THEORY}

Practice-theory plays an important role in explaining the philosophical and social nature of human engagement, which includes teaching. On the philosophical front, Schatzki indicates that practice theorists are concerned about the epistemology of practice (how humans create knowledge), and the ontology of practice (how that knowledge is enacted in various contexts). On the social front, the focus for practice theorists are on subjectivity, embodiment, meaning, and the reproduction and transformation of the self. Essentially the essence is how practices create and influence the social constructions of one's reality and thus informing one's practice(s) (Schatzki 2001, 10).

Despite practice-theory contributing to the social or philosophical issues of practice, practice theorists have debated whether practices develop individually or within a collective. There is a notion that practices are governed by the historical and/or experiential knowledge, beliefs and ideas of the collective, and thus embodied by the individual. Expanding on this notion, practice theorists, such as Schatzki (2001), Bazin (2010) and Elkjaer (2005) allude to the idea that despite practices being enacted individually, they are created collectively. Thus, theorists, such as Schatzki (2001) and Corradi, Gherardi and Verzelloni (2010) view practices as the medium for human development and change.

According to Schatzki $(2001,12)$ practices are viewed as an "array of human activity, socially mediated by humans, using human or non-human artefacts, being dependant on shared skills and being context-dependent". Corradi et al. (2010, 268), on the other hand, define practice theory along two dimensions. First, they view practices as an empirical object whereby the practice becomes the focal point of the study. Secondly, practices are a way of seeing, that is, how the practitioner context influences the process of knowledge construction, and the enactment of the practice within the organisation or institution. If we were then to percolate these two viewpoints, then the commonality would be that practices are created and governed by the context of the practitioner, and that practices manifest themselves, as an empirical object, via social mediation; a sort of coming together of practitioners to create a discourse around practice. For Schatzki (2001) and Corradi et al. (2010), the context in which the practitioner finds itself becomes the driving force for the creation of new practices, which implies that the practice(s) are not only about "what we do", or "what we say" but also more importantly, where the practice is enacted. This post-modernist view of practices by Corradi et al. (2010), Kemmis (2011) and Webster-Wright (2009) entails the evolution of practices as sometimes being dependant on non-human artefacts, such as context. They contend that context is one of the crucial driving forces for creating new practices the locus of the contexts maps out the practices 
to be enacted.

There are various theories of practice. As far back as 1966, Polanyi viewed practices as the platform for developing skills and new knowledge or ideas. This view was based on his notion of tacit knowledge underpinning the activities leading to the development of the practice. This idea was linked to the now famous aphorism "we know more than we can tell" $(1966,4)$. Schatzki $(2001,12)$ views practices as a composition of human activities linked to the "doings and sayings" of human engagement, leading to the assumption that for any practice "we know more than we can tell" via our "doings and sayings". However, whatever view about practice is expressed, most practice theorists agree that there is a central core of practice theory. This core involves the idea that practices are embodied, materially mediated arrays of human activity centrally organised around shared practical understanding (Schatzki 2001). Using the notion of embodiment in referring to practices is linked to the idea that the very nature of practices involves human behaviour, such as emotions, behaviours, beliefs and attitudes, which are critical in the production of new practices and knowledge, namely the epistemology of practices. This epistemology then informs the production of the new practice, that is, the becoming, being, understanding and purpose of that practice, namely, the ontology of the practice. As Schatzki (2001) purports, the body becomes the meeting point of both the mind (theory) and activity (practice or enactment).

Practice theorist such as Bazin (2010) also note that despite the learning of a practice being a shared process within a collective, the practice is enacted individually. However, the experience of the practice is then shared in a collective. Elkjaer $(2005,49)$ concurs as he states that because learning via inquiry and experiences involves process both at the individual and collective level, learning a new practice entails a process of knowledge creation (collectively) and a process of enactment and reflection (individually), whilst becoming a practitioner.

Other points of agreement amongst practice theorists is that there are no set rules or patterns that determine how a practice is enacted (Schatzki 2001; Barnes 2001). Practices vary from context to context and as such, are not bounded by formal theories of learning and behaviour on how they should be enacted within a particular context. Practices also provide the platform for human change and development. The development of this change is guided by the "doings and sayings" or thoughts and ideas whilst engaging in a social collective.

Summarising, practices are context dependent activities, governed by our own thoughts and innovations, not constraint by formal theories of learning and behaviour. They are created and mediated socially, linked by a shared practical understanding amongst the collective, leading to knowledge creation and reflection around the new practice. Practices are governed by the historical and/or experiential knowledge, beliefs and ideas of the collective, and thus 
embodied, or owned, by the individual. Despite the learning of a practice being a shared activity, practices are enacted individually. Learning about a new practice entails the process of knowledge creation, that is the epistemology of the practice, and the process of enactment and becoming the practitioner, that is, the ontology of the practice. These distinctive elements of practice theory, according to practice theorists, are considered the unique elements for human development and change, and could thus be infused within professional learning to minimise the theory-practice divide.

\section{PROFESSIONAL LEARNING FOR TEACHERS}

McCormack, Gore and Thomas (2006), purport that traditional teacher learning has been linked to formal, planned in-service activities using a deficit model which includes "experts" from outside informing teachers of the knowledge, skills or resources they require for teaching. This approach reflects the knowledge transmission mode of teaching. However, in recent times there has been a shift, where training initiatives encourage teachers to reflect and actively participate in the training as part of their professional growth and development. This approach is termed professional learning, where teachers' knowledge, understanding, skills are transformed as they practice individually and socially. Webster-Wright (2009. 715) refers to the idea of professional learning as engaging in "authentic tasks that are genuine and embedded in real life". Alluding to the contextual nature of practices and that professional learning takes place within the social and situated nature of the practitioner.

And since the tasks are "genuine and embedded", we could argue that professional learning is where the "thinking and the doing" or "theory and practice" of the task is inextricably linked. For Webster-Wright (2009, 724-725), professional learning is: "Embedded and constructed in the experience of being a professional in practice ... practice is not a situation separate from the professional, but a social, dynamic, and integral part of being a professional working in the current context".

According to Opfer and Pedder (2011), research indicates that activities that sustain professional learning for teachers should be continuous (an appropriate number of contact hours over a lengthy period) and intensive, rather than brief and sporadic. Furthermore, teachers learn most effectively when teachers engage with the materials of practice (intensive), when the learning activity is school based (contextually determined) and integrated into their professional lives/daily teaching/classrooms and when the pedagogy is linked to learning in ways that require reflection on how their pupils should be taught.

In promoting professional learning as a mechanism to minimise the theory-practice gap, Timperley $(2008,11)$ states that to promote teacher understanding and effective changes in 
practice, professional learning programmes should integrate theories of curriculum. Effective teaching and assessment must be developed in tandem with applications to practice. Modes of teacher education programmes that combine theory with practice have a positive effect on the efficacy of teaching. Similarly, Boud and Middleton (2003) suggest that for any successful professional learning to take place, learning as a practice should be investigated as learning is not a separate practice; it should be integrated, sustained and perpetuated in practice, within any given context. According to Ball and Cohen (1999), much of what teachers need to learn and know should be learned within the moment and context of the practice; since knowledge is situated in practice, it must be learned in practice.

Returning, then, to the theory-practice debate, and foregrounding Aristotelian notions of phronesis, poiesis and praxis, the thought processes behind any practice (phronesis) is always dependent on how and where the practice will be enacted (context) and what constitutes the practice (poiesis) (creation of new knowledge) and finally leading to the enactment of the practice (praxis). Viewing the creation of new knowledge and practices from this Aristotelian perspective, we are reminded, by Davids and Waghid (2017), that the manifestation and enactment of any practice is never made up of two distinct processes, namely theory and practice, but the two form a nexus to enhance learning and practice.

Boud and Rooney (2011) argue that professional learning should be based on what professionals do to continue their learning and it should be linked to the kinds of practices that can be sustained within their work context. It is for this reason that these authors suggest that professional learning should be viewed within the framework and dimensions of practice theory. They define learning as a set of practices whose purpose it is to realise the learning of the professional. Ball and Cohen (1999) and Boud and Rooney (2011) thus seem to suggest that professional learning should focus on the intermingling of theory and practice, where teachers become serious learners in and around their practice. This process of intermingling theory and practice within a professional learning environment also resonates with Raelin $(2007,495)$ who argues that the purpose of theory is to inform practice and theory loses its meaning if not reflected upon in practice.

\section{PRACTICE-BASED TEACHER PROFESSIONAL LEARNING}

Teacher professional learning has been conceptualised as an activity that is continuous, sustained and enacted within the teaching context of the teacher (Bruce et al. 2010; Opfer and Pedder 2011). Learning of new knowledge should also be intensive as opposed to finite and random acts of training. Boud and Rooney (2011); Ball and Cohen (1999) and Boud and Middleton (2003), suggest that for any successful professional learning to take place, learning 
should be sustained, integrated and perpetuated in practice and new knowledge and theories around practice should be learnt within practice. According to Webster-Wright (2009), to minimise the theory-practice gap, professional learning needs to be invoked. Moreover, because of this, professional learning should be viewed within the framework and dimensions of practice theory, leading to a set of practices that could enhance the learning of the professional. By intermingling theory and practice, teachers could become serious learners in and around their practice and thus bridge the theory-practice gap.

By incorporating these elements of practice theory within the professional learning of teachers, new practices are developed when sharing is initiated and information is transformed into new knowledge within socially mediated spaces (Schatzki 2001; Collins 2001). When teachers engage with other teachers in socially mediated and supportive environments, theoretical knowledge can be transformed into practical knowledge within their own context. When new content is learnt within a collegial and collaborative or socially mediated spaces, strong conceptual understanding of the content/new knowledge can be created (Peters 1967).

For Korthagen et al. (2006) and Ball (2000), when combining theory with practice within teacher professional learning programmes, a deep understanding of the content for teaching is created, thus reducing the dichotomous nature of the theory-practice divide. By collectively or individually sharing their experiences, teachers should embody or integrate these into their consciousness leading to the development of new practices.

This transformation can be further strengthened if teachers from similar context, socially and professionally, engage with each other. What the elements of practice theory also imply is that when theoretical knowledge is transformed, new practices evolve. Subsequently teachers can take ownership of this new practice and embody it as part of their being. This embodiment of new practices could lead to teachers taking risks by experimenting with new practices within their classroom teaching and learning. Embodiment and ownership of their own professional learning, could lead to teachers adapting their new practices within any teaching context. Practices evolve when professional learning environments are not governed by a set of rules or procedures (Barnes 2001). The evolution of new practices is driven by innovation that is free from theoretical constructs and concepts. Creating new thoughts around pedagogies, linked to their beliefs and experiences within various contexts, is what drives teachers to improve their practices; not decided upon by a one size fits all set of procedures and rules.

We thus argue that by incorporating the elements of practice theory within teacher professional learning programmes, we propose an alternative to the current theory laden teacher education programmes called the practice-based teacher professional learning. We propose that teacher education programmes, incorporating these unique elements of practice theory within 
professional learning for teachers, should include aspects of learning that are continuous, intensive, contextual (situated), socially mediated, supportive and embodied. These continuous, intensive, situated, socially mediated, supportive and embodied aspects of learning should relate to the contextual needs of the teacher by invoking the Aristotelian notions of phronesis, poiesis and praxis, thus minimising the theory-practice gap.

\section{CONCLUSION}

Leading researchers such as Timperley (2008), Boud and Rooney (2011) and Raelin (2007) suggest that to minimise the theory-practice divide within teaching, professional learning should be based on practice theory; a professional learning approach that calls for a combination of theory and practice. A kind of teaching and learning for teachers in which teachers become serious learners in and around their practice, rather than superficially implementing strategies and activities learnt at workshops, invoking the Aristotelian notions of phronesis, poiesis and praxis. Extending on the notion of using practice theory within professional learning programmes, as a mechanism to bridge the theory-practice gap in teacher professional learning programmes, we suggest ideas or principles to combine theory with practice within professional learning programmes, and consequently reduce the theory and practice divide.

By incorporating elements of practice theory into teacher professional learning, we argue for practice-based teacher professional learning as an alternative mode of teacher education programmes to bridge the theory-practice divide, wherein the focus is on learning that is continuous, intensive, contextual (situated), socially mediated, supportive and embodied. Implications for further research would be to report on how effective this approach could be in practice. Another suggestion for further research would be to conceptualise, based on the elements of the practice-based teacher professional learning approach, the components of a such an approach and how these components could be enacted in practice.

\section{REFERENCES}

Adler, J. and H. Venkat. 2014. Teachers' mathematical discourse in instruction: Focus on examples and explanations. In Exploring mathematics and science teachers' knowledge: Windows into teacher thinking, ed. H. Venkat, M. Rollnick, J. Loughran and M. Askew, 132-146. Abingdon, Oxon: Routledge.

Anderson, M. J. and K. Freebody. 2012. Developing communities of praxis: Bridging the theory practice divide in teacher education. McGill Journal of Education 47(3): 359-377. Fall.

Ball, D. and H. Bass. 2000. Interweaving content and pedagogy in teaching and learning to teach: knowing and using mathematics. Multiple perspectives on the teaching and learning of mathematics, 83-104.

Ball, D. L. 2000. Bridging practices: Intertwining content and pedagogy in teaching and learning to teach. Journal of Teacher Education 51(3): 241-247. 
Ball, Deborah Loewenberg and David K. Cohen. 1999. "Developing practice, developing practitioners: Toward a practice-based theory of professional education." Teaching as the Learning Profession: Handbook of Policy and Practice 1(3): 3-22.

Barnes, B. 2001. Practice as collective action. In The practice turn in contemporary theory, ed. Theodore R. Schatzki, Karin Knorr Cetina and Eike Von Savigny, 25-36. Psychology Press.

Bazin, Y. 2010. The practice perspective, a field under tension. In 26th EGOS Colloquium, 1-10.

Boud, D. and H. Middleton. 2003. Learning from others at work: Communities of practice and informal learning. Journal of Workplace Learning 15(5): 194-202.

Boud, D. and D. Rooney. 2011. A practice approach to studying professional learning: "Can't get no satisfaction", 1-9. https://scholar.google.co.za/scholar?q=practice+approach+to+professional+ learning...can $\% 27 \mathrm{t}+$ get + no + satisfaction $\% 2 \mathrm{C}+$ Boud $\& b \operatorname{bnG}=\& \mathrm{hl}=\mathrm{en} \&$ as_sdt $=0 \% 2 \mathrm{C} 5 \quad$ (Accessed 21 April 2019).

Bruce, C. D., E. Indigo, J. Ross, L. Dookie and R. Beatty. 2010. The effects of sustained classroomembedded teacher professional learning on teacher Ef Fi Cacy and related student achievement. Teaching and Teacher Education 26(8): 1598-1608.

Carr, W. 2006. Education without theory. British Journal of Educational Studies 54(2): 136-159.

Collins, H. M. 2001. What is tacit knowledge? In The practice turn in contemporary theory, ed. Theodore Schatzki, Karen Knorr Cetina and Eike von Savigny, 115-128. Psychology Press.

Corradi, G., S. Gherardi and L. Verzelloni. 2010. Through the practice lens: Where is the bandwagon of practice-based studies heading? Management Learning 41(3): 265-283.

Davids, N. 2019. Democratic citizenship education in South Africa: Can we trust our teachers? In Handbook of research on education for participative citizenship and global prosperity, ed. J. A. Pineda-Alfonso, N. De Alba-Fernández and E. Navarro-Medina, 45-66. Pennsylvania: IGI Global International publisher.

Davids, N. and Y. Waghid. 2017. Educational theory as rhythmic action: From Hannah Arendt to Giorgio Agamben. South African Journal of Higher Education 31(5): 1-13.

Elkjaer, B. 2005. Social learning theory: Learning as participation in social processes. In The Blackwell Handbook of Organizational Learning and Knowledge Management, ed. M. A. Easterby-Smith and Mark Lyles, 38-53. Blackwell Publishing.

Farber, B. A. and L. D. Wechsler. 1991. Crisis in education: Stress and burnout in the American teacher. San Francisco, CA: Jossey Bass.

Feiman-Nemser, S. 2001. From preparation to practice: Designing a continuum to strengthen and sustain teaching. Teachers College Record 103(6): 1013-1055.

Gravett, S. and S. Ramsaroop. 2015. Bridging theory and practice in teacher education: Teaching schools - a bridge too far? Perspectives in Education 33(1): 131-146.

Henning, E. and S. Gravett. 2011. Pedagogical craft and its science: Janus-faced in pre-service teacher education. Education as Change 15(1): 21-33.

Higgs, L. G. 2013. "Theory in educational research and practice in teacher education", Bulgarian Comparative Education Society, Paper presented at the Annual International Conference of the Bulgarian Comparative Education Society. 11th, Plovdiv, Bulgaria, May 14-17, 2013.

Hirst, P. H. 1963. Philosophy and educational theory. British Journal of Educational Studies 12(1): 5164.

Imig, D. G. and T. J. Switzer. 1996. Changing teacher education programs: Restructuring collegiatebased teacher education. In Handbook of research on teacher education, ed. J Sikula, 213-226. $2^{\text {nd }}$ Edition. New York: McMillan.

Jeram, R. 2017. On bridging the gap between theory and practice: A conceptual analysis of practice in relation to a teacher professional learning programme at Stellenbosch University. Unpublished $\mathrm{PhD}$ thesis.

Kiggundu, E. and S. Nayimuli. 2009. Teaching practice: A make or break phase for student teachers, 
South African Journal of Education 29: 345-358.

Kemmis, Stephen. 2011. What is professional practice? Recognising and respecting diversity in understandings of practice. In Elaborating professionalism: Studies in practice and theory, 1-31.

Kennedy, M. 2016. Parsing the practice of teaching. Journal of Teacher Education 67(1): 6-17.

King, M. B. and F. M. Newman. 2001. Building school capacity through professional development: Conceptual and empirical considerations. The International Journal of Educational Management 15(2): 86-94.

Korthagen, F. A. J. and M. Kessels. 1999. Linking theory and practice: Changing the pedagogy of teacher education. Educational Researcher 28(4): 4-17.

Korthagen, F. A. J. 2001. Linking practice and theory: The pedagogy of realistic teacher education. In Annual Meeting of the American Educational Reserach Association 28: 1-16.

Korthagen, F. A. J., J. Loughran and T. Russell. 2006. Developing fundamental principles for teacher education programs and practices. Teaching and Teacher Education 22(8): 1020-1041.

Mccormack, A., J. Gore and K. Thomas. 2006. Early career teacher professional learning early career teacher professional learning. Asia-Pacific Journal of Teacher Education 34(1): 95-113.

NEEDU. 2012. "National Education Evaluation and Development Unit 2012 Report." http://www.saqa.org.za/docs/papers/2013/needu.pdf

Opfer, V. D. and D. Pedder. 2011. Conceptualizing teacher professional learning. Review of Educational Research 81(3): 376-407.

Peters, R. S. 1967. "What is an educational process?” In The concept of education, ed. R. S. Peters, 116. Routledge \& Kegan Paul Ltd.

Polanyi, Michael. 1966. The tacit dimension. Chicago: University of Chicago Press.

Pournara, C., J. Hodgen, J. Adler and V. Pillay. 2015. Can improving teachers' knowledge of mathematics lead to gains in learners' attainment in Mathematics? South African Journal of Education 35(3): 1-10.

Raelin, J. A. 2007. Toward an epistemology of practice. Academy of Management Learning and Education 6(4): 495-519.

Rusznyak, L. 2018. What messages about teacher professionalism are transmitted through South African pre-service teacher education programmes? South African Journal of Education 38(3): 1-11.

Ryle, Gilbert. 1945. "Knowing how and knowing that: The Presidential address." In Proceedings of the Aristotelian Society 46: 1-16. http://www.jstor.org/stable/4544405

Sayed, Y., N. Carrim, A. Badroodien, Z. McDonald and M. Singh. (Ed.). 2018. Learning to teach in post-apartheid South Africa - Student teacher' encounters with initial teacher encounters. Cape Town: AFRICAN SUN MeDIA.

Schatzki, T. 2001. Introduction: Practice theory. In The practice turn in contemporary theory, ed. T. Schatzki, K. K. Cetina and E. von Savigny, 10-23. Psychology Press.

Spaull, N. 2013. "South Africa's education crisis: The quality of education in South Africa 1994-2011." Johannesburg: Centre for Development and Enterprise.

Steyn, G. M. 2008. Continuing professional development for teachers in South Africa and social learning systems: Conflicting conceptual frameworks of learning. Koers 73(1):15-31.

Thomas, G. 1997. What's the use of theory? Harvard Educational Review 67(1): 75-104

Timperley, H. 2008. Teacher professional learning and development (EDUCATIONAL PRACTICES SERIES - 18. http://edu.aru.ac.th/childedu/images/PDF/benjamaporn/EdPractices_18.pdf

Van der Berg, S. and H. Hofmeyr. 2017. "South African education: Background note for World Bank's South African country diagnostic." Research on Socio-Economic Policy. World Bank.

Van der Berg, S., N. Spaull, G. Wills, M. Gustafsson and J. Kotze. 2016. Identifying binding constraints in education. http://resep.sun.ac.za/wp-content/uploads/2016/06/PSPPD_BICiE-email-0106 
2016.pdf (Accessed 20 September 2016).

Waghid, Y. and N. Davids. 2017. Philosophy and education as action-implications for teacher education. Lanham, MD: Lexington Books.

Webster-Wright, A. 2009. Reframing professional development through understanding authentic professional learning. Review of Educational Research 79(2): 702-739.

Zeichner, K. 2010. Rethinking the connections between campus courses and field experiences in college and university-based teacher education. Journal of Teacher Education XX(X): 1-11. 